\title{
Design, Synthesis and Biological Evaluation of New HDACl and HDAC2 Inhibitors Endowed with Ligustrazine as a Novel Cap Moiety
}

This article was published in the following Dove Press journal: Drug Design, Development and Therapy

\author{
Mohammad M Al-Sanea,' \\ Lizaveta Gotina, ${ }^{2}$ \\ Mamdouh FA Mohamed, ${ }^{3}$ \\ Della Grace Thomas Parambi, \\ Hesham A M Gomaa, ${ }^{4,5}$ \\ Bijo Mathew, ${ }^{6}$ \\ Bahaa G M Youssif, (D) \\ Khalid Saad Alharbi, $\mathbb{1 D}^{8}$ \\ Zainab M Elsayed, ${ }^{9}$ \\ Mohamed A Abdelgawad, (1D ${ }^{1,10}$ \\ Wagdy M Eldehna ${ }^{9,11}$ \\ 'Department of Pharmaceutical Chemistry, \\ College of Pharmacy, Jouf University, Sakaka, Aljouf \\ 2014, Saudi Arabia; ${ }^{2}$ Division of Bio-Medical \\ Science \& Technology, KIST School, Korea \\ University of Science and Technology (UST), \\ Daejeon, Korea; ${ }^{3}$ Department of Pharmaceutical \\ Chemistry, Faculty of Pharmacy, Sohag University, \\ Sohag 82524, Egypt; ${ }^{4}$ Department of \\ Pharmacology, College of Pharmacy, Jouf \\ University, Sakaka, Aljouf 2014, Saudi Arabia; \\ ${ }^{5}$ Department of Biochemistry, Faculty of Pharmacy, \\ Nahda University, Beni-Suef, Egypt; ${ }^{6}$ Division of \\ Drug Design and Medicinal Chemistry Research \\ Lab, Department of Pharmaceutical Chemistry, \\ Ahalia School of Pharmacy, Palakkad, Kerala \\ 678557, India; ${ }^{7}$ Department of Pharmaceutical \\ Organic Chemistry, Faculty of Pharmacy, Assiut \\ University, Assiut 71526, Egypt; ${ }^{8}$ Department of \\ Pharmacology, College of Pharmacy, Jouf \\ University, Sakakah 7234I, Saudi Arabia; '9 Scientific \\ Research and Innovation Support Unit, Faculty of \\ Pharmacy, Kafrelsheikh University, Kafrelsheikh, \\ Egypt; ${ }^{10}$ Department of Pharmaceutical Organic \\ Chemistry, Beni-Suef University, Beni-Suef 62514, \\ Egypt; "Department of Pharmaceutical Chemistry, \\ Faculty of Pharmacy, Kafrelsheikh University, \\ Kafrelsheikh, Egypt
}

Correspondence: Mohammad M Al-Sanea Department of Pharmaceutical

Chemistry, College of Pharmacy, Jouf

University, Sakaka, Aljouf 2014, Saudi

Arabia

Tel +966594076460

Email mmalsanea@ju.edu.sa
Introduction: Histone deacetylases (HDACs) represent one of the most validated cancer targets. The inhibition of HDACs has been proven to be a successful strategy for the development of novel anticancer candidates.

Methods: This work describes design and synthesis of a new set of HDAC inhibitors (7a-c and $\mathbf{8 a}, \mathbf{b})$ utilizing ligustrazine as a novel cap moiety, and achieving the pharmacophoric features required to induce the desired inhibition.

Results: The newly synthesized derivatives were evaluated for their potential inhibitory activity toward two class I histone deacetylases, namely HDAC1 and HDAC2. The tested ligustrazine-based compounds were more potent toward HDAC2 ( $\mathrm{IC}_{50}$ range: 53.7-205.4 nM) than HDAC1 ( $\mathrm{IC}_{50}$ range: 114.3-2434.7 nM). Furthermore, the antiproliferative activities against two HDAC-expressing cancer cell lines; HT-29 and SH-SY5Y were examined by the MTT assay. Moreover, a molecular docking study of the designed HDAC inhibitors (7a-c and 8a,b) was carried out to investigate their binding pattern within their prospective targets; HDAC1 (PDB-ID: 4BKX) and HDAC2 (PDB-ID: 6G3O).

Discussion: Compound 7a was found to be the most potent analog in this study toward $\mathrm{HDAC} 1$ and HDAC2 with $\mathrm{IC}_{50}$ values equal 114.3 and $53.7 \mathrm{nM}$, respectively. Moreover, it was the most effective counterpart $\left(\mathrm{IC}_{50}=1.60 \mu \mathrm{M}\right)$, with 4.7 -fold enhanced efficiency than reference drug Gefitinib $\left(\mathrm{IC}_{50}=7.63 \mu \mathrm{M}\right)$ against $\mathrm{SH}-\mathrm{SY} 5 \mathrm{Y}$ cells. Whereas, compound $\mathbf{8 a}$ $\left(\mathrm{IC}_{50}=1.96 \mu \mathrm{M}\right)$ was the most active member toward HT-29 cells, being 2.5-times more potent than Gefitinib $\left(\mathrm{IC}_{50}=4.99 \mu \mathrm{M}\right)$. Collectively, these results suggest that 7 a merits further optimization and development as an effective new HDACI lead compound.

Keywords: HDACs Inhibitors, Ligustrazine, Anticancer agents, In silico study, Synthesis

\section{Introduction}

Health and diseases are always governed by the highly intricate and regulated actions of a wide armory of transcription factors. The fundamental organic structure of DNA is the nucleosome, which consists of strands of DNA wrapped around a core of 8 histone proteins. ${ }^{1}$ The amino acid residues protruded from the ' $\mathrm{N}$ - and ' $\mathrm{C}$ - on the histone tail are modified by enzyme-driven post-translational acetylation, methylation, and phosphorylation. ${ }^{2,3}$ These modifications increase the accessibility of transcription factors to gene promoter regions. Deacetylation, demethylation, and dephosphorylation of histones have the opposite effect of decreasing access of transcription factors to promoter regions. Emerging data now implicate histone modification in the pathobiology of cancer and other diseases. Histone acetylation 
is mediated by histone acetyltransferases, while acetyl groups are removed by histone deacetylases (HDACs). Recently, the use of HDACs as targeted agents has gained much popularity as a more safe and effective alternative for cancer therapy than classical agents. ${ }^{4-7}$ Because of the cellular overexpression of HDACs has been reported in the vast majority of human tumors, there is substantial interest to develop more selective and potent inhibitors for these enzymes. $^{6,7}$

HDAC is known to have 18 isoforms classified into 4 classes (class I-IV) and among these 4 classes, mainly class $\mathrm{I}$ is proven to be associated with tumor proliferation. ${ }^{8}$ It is hypothesized that HDAC-isoform-selective inhibitors would have improved efficacy and minimal adverse effects; thus, isoform-selective compounds have been developed. To date, a few HDAC inhibitors have approved by FDA which include: Vorinostat $\left(\right.$ Zolinza $\left.^{\circledR}\right)$ and Romidepsin (Istodax $\left.{ }^{\circledR}\right)$ for cutaneous T- cell lymphoma, ${ }^{9,10}$ Panobinostat $\left(\right.$ Farydak $^{\circledR}$ ) for multiple myeloma, ${ }^{11}$ in addition to Belinostat (Beleodaq ${ }^{\circledR}$ ) and Chidamide $\left(\right.$ Epidaza $^{\circledR}$ ) both for use in peripheral T-cell lymphoma. ${ }^{12,13}$

Generally, the essential topological pharmacophoric features for HDAC inhibitors (HDACIs) contain four basic components. The first one is the zinc-binding group ( $\mathrm{ZBG})$ that coordinates the $\mathrm{Zn}^{2+}$ at the bottom of the enzyme cavity; the second one is a cap group (CAP) that interacts with the rim of the catalytic tunnel of the enzyme; the third one is a polar connection unit (CU, apparently dispensable for HDAC8 selective inhibitors) connecting to the fourth pharmacophore which is a linker (hydrophobic spacer) enabling the inhibitor to lie into the aforementioned tunnel (Figure 1). ${ }^{6}$

Ligustrazine (TMP, 2,3,5,6-tetramethylpyrazine) is originally a natural product extracted from Ligusticum chuanxiong Hort, a Chinese traditional medicinal herb, that is widely used as clinical medication for occlusive cerebrovascular diseases. ${ }^{14}$ Ligustrazine has recently been reported to be a well-validated adjuvant in the reversal of multidrug resistance (MDR) in tumor cells, in addition to its ability to inhibit growth, invasion and metastasis of tumor cells. ${ }^{15,16}$ Accordingly, ligustrazine has attracted considerable attention as a privileged scaffold in cancer drug discovery. In this context, several studies reported the development of different ligustrazine-based hybrids such as ligustrazine-curcumin hybrids, ${ }^{17,18}$ ligustrazine-terpenes hybrids ${ }^{19}$ and others. ${ }^{20,21}$

The aforementioned findings have inspired and guided us to design and synthesize a new set of HDAC inhibitors (7a-c and 8a,b) utilizing ligustrazine as a novel cap moiety, and achieving the pharmacophoric features required to induce the desired inhibition (Figure 1). The newly synthesized ligustrazine-based derivatives (7a-c and $\mathbf{8 a}, \mathbf{b})$ were evaluated for their potential inhibitory activity toward two class I histone deacetylases, namely HDAC1 and HDAC2. Furthermore, their antiproliferative activities against two HDAC-expressing cancer cell lines, colorectal adenocarcinoma (HT-29) and neuroblastoma (SH-SY5Y) cell lines, were examined by the MTT assay.

\section{Materials and Methods Chemistry}

Melting points were determined on an electrothermal melting point apparatus (Stuart Scientific Co.) and were uncorrected. NMR spectra were recorded on a Bruker Avance III HD NMR spectrometer. ${ }^{1} \mathrm{H}$ spectrum was run at 400 $\mathrm{MHz}$ and ${ }^{13} \mathrm{C}$ spectrum was run at $100 \mathrm{MHz}$ in deuterated dimethylsulfoxide (DMSO- $\left.d_{6}\right)$. Chemical shifts were expressed in ppm using the solvent peak as internal standard. $^{22}$ All coupling constant $(J)$ values were given in hertz. The abbreviations used are as follows: s, singlet; $\mathrm{d}$, doublet; m, multiplet. Analytical thin-layer chromatography (TLC) on silica gel plates containing UV indicator was employed routinely to follow the course of reactions.

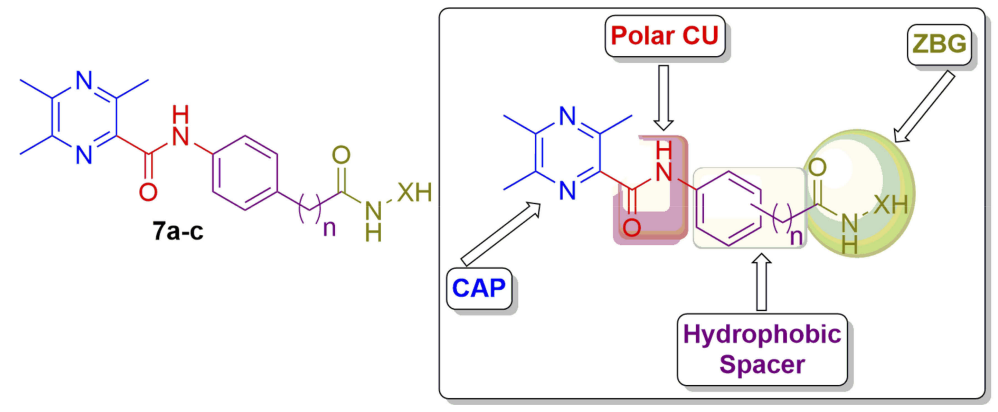

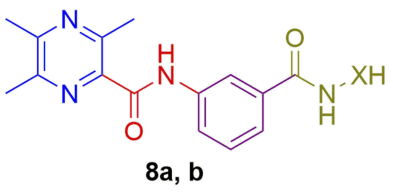

ZBG: zinc-binding group CAP: cap group

$\mathrm{CU}$ : polar connection unit

Figure I Design and general structures of target compounds (7a-c and $\mathbf{8 a}, \mathbf{b})$. 


\section{Synthesis of 3,5,6-Trimethylpyrazine-2-Carboxylic} Acid 2

To a solution of TMP $(5 \mathrm{~g}, 36.8 \mathrm{mmol})$ in water $(200 \mathrm{~mL})$, aqueous $\mathrm{KMnO}_{4}$ solution $\left(8.6 \mathrm{~g} \mathrm{KMnO}_{4}: 150 \mathrm{~mL}\right.$ water) was added dropwise at room temperature (r.t.) over about $60 \mathrm{~min}$. Upon completion of the addition, the mixture was stirred at $50^{\circ} \mathrm{C}$ for $12 \mathrm{~h}$, and then the warm reaction mixture was filtered and washed with hot water $(300 \mathrm{~mL}$, $90^{\circ} \mathrm{C}$ ). The filtrate and washing liquid were combined, cooled to $0-5^{\circ} \mathrm{C}$, and the $\mathrm{pH}$ adjusted to 2.0 with concentrated hydrochloric acid. Extraction was performed with ethyl acetate $(200 \mathrm{~mL} \times 3)$, and the organic phase was dried with anhydrous sodium sulfate. The solvent was removed by distillation under vacuum, and the residue was recrystallized from acetone to produce a light-yellow solid $(2.39$ g, yield: $48 \%)$, m.p.: $162-163^{\circ} \mathrm{C}$ as reported. ${ }^{19}$

Synthesis of Key Intermediates $4 a, b$ and 6

3,5,6-Trimethylpyrazine-2-carboxylic acid 2 (1.66 g, $10 \mathrm{mmol}$ ) was added to a suspension of 1,1-carbonyldiimidazole (CDI, $50 \mathrm{mmol}$ ) in dry tetrahydrofuran (THF, $20 \mathrm{~mL}$ ) and the mixture was stirred for $2 \mathrm{~h}$ at r.t. Then, the corresponding acid $(50 \mathrm{mmol})$ and trifluoroacetic acid (TFA, $2.4 \mathrm{~mL}$ ) were added and stirred for additional $10 \mathrm{~h}$ at r.t. The reaction mixture was evaporated to afford the key intermediates $4 a, b$ and 6 that used in the next step without further purification.

\section{Synthesis of Target HDAC Inhibitors 7a-c and 8a,b}

To a suspension of key intermediates $4 \mathrm{a}, \mathrm{b}$ and $6(5 \mathrm{mmol})$ in dry THF $(10 \mathrm{~mL})$, CDI $(19 \mathrm{mmol})$ was added, and the mixture was stirred for $3 \mathrm{~h}$ at $60^{\circ} \mathrm{C}$. The clear solution was cooled to r.t. then hydrazine hydrate hydrochloride or hydroxylamine hydrochloride $(25 \mathrm{mmol})$ was added. The reaction mixture was stirred for $6 \mathrm{~h}$ then evaporated to remove THF, and the crude product was stirred in water for $1 \mathrm{~h}$ and filtered and dried. The residue was purified by column chromatography using dichloromethane: methanol (9:1) to furnish target compounds 7a-c and 8a,b.

$\mathrm{N}$-(4-(Hydrazinecarbonyl)phenyl)-3,5,6-Trimethylpyrazine2-Carboxamide (7a)

Yield 55\%, m.p. $>250{ }^{\circ} \mathrm{C} ;{ }^{1} \mathrm{H}$ NMR (DMSO- $d_{6}, 400 \mathrm{MHz}$ ) $\delta$ ppm: 2.54 (s, 3H, 6- $\left.\mathrm{CH}_{3}\right), 2.56$ (s, 3H, 5- $\left.\mathrm{CH}_{3}\right), 2.71(\mathrm{~s}, 3 \mathrm{H}$, 3- $\mathrm{CH}_{3}$ ), 4.53 (bs, NH $\mathrm{N}_{2}$ ), 7.52-7.90 (m, 4H, Ar-H), 9.67 (s, 1H, $\mathrm{NHNH}_{2}$ ), 10.59 (s, 1H, NHCO); ${ }^{13} \mathrm{C}$ NMR (DMSO- $d_{6}, 100$ MHz) $\delta$ ppm: $21.44\left(6-\mathrm{CH}_{3}\right), 22.12\left(5-\mathrm{CH}_{3}\right), 22.33\left(3-\mathrm{CH}_{3}\right)$, $119.67,128.19,128.80,141.05,141.80,148.71,149.86$, 154.57, $164.61(\mathrm{C}=\mathrm{O}), 165.93(\mathrm{C}=\mathrm{O})$.
N-(4-(2-(Hydroxyamino)-2-Oxoethyl)phenyl)-

3,5,6-Trimethylpyrazine-2-Carboxamide (7b)

Yield $60 \%$, m.p. $>250{ }^{\circ} \mathrm{C} ;{ }^{1} \mathrm{H}$ NMR (DMSO- $d_{6}, 400 \mathrm{MHz}$ ) $\delta$ ppm: 2.54 (s, 3H, 6- $\mathrm{CH}_{3}$ ), 2.56 (s, 3H, 5- $\mathrm{CH}_{3}$ ), 2.71 (s, 3H, 3- $\left.\mathrm{CH}_{3}\right), 3.57\left(\mathrm{~s}, 2 \mathrm{H}, \mathrm{CH}_{2} \mathrm{CO}\right), 7.08(\mathrm{~s}, 1 \mathrm{H}, \mathrm{NHOH}), 7.18-7.76$ (m, 4H, Ar-H), 10.03 (s, 1H, NHCO), 10.58 (s, NHOH); ${ }^{13} \mathrm{C}$ NMR (DMSO- $\left.d_{6}, 100 \mathrm{MHz}\right) \delta$ ppm: $21.44\left(6-\mathrm{CH}_{3}\right)$, $22.09\left(5-\mathrm{CH}_{3}\right), 22.57\left(3-\mathrm{CH}_{3}\right), 29.50\left(\mathrm{CH}_{2} \mathrm{CO}\right), 119.50$, $120.42,129.83,131.28,131.93,137.51,138.11,141.42$, 149.62, 154.28, $167.60(\mathrm{C}=\mathrm{O}), 169.53(\mathrm{C}=\mathrm{O})$.

N-(4-(2-Hydrazinyl-2-Oxoethyl)phenyl)-

3,5,6-Trimethylpyrazine-2-Carboxamide (7c)

Yield $48 \%$, m.p. $>250{ }^{\circ} \mathrm{C} ;{ }^{1} \mathrm{H}$ NMR (DMSO- $d_{6}, 400 \mathrm{MHz}$ ) $\delta$ ppm: 2.51 (s, 3H, 6- $\left.-\mathrm{CH}_{3}\right), 2.54$ (s, 3H, 5- $\left.\mathrm{CH}_{3}\right), 2.71(\mathrm{~s}, 3 \mathrm{H}$, 3- $\mathrm{CH}_{3}$ ), 3.57 (s, 2H, $\mathrm{CH}_{2} \mathrm{CO}$ ), 4.39 (bs, $\mathrm{NH}_{2}$ ), 7.08 (s, 1H, $\mathrm{NHOH}), 7.17-7.74(\mathrm{~m}, 4 \mathrm{H}, \mathrm{Ar}-\mathrm{H}), 9.12\left(\mathrm{~s}, 1 \mathrm{H}, \mathrm{NHNH}_{2}\right)$, 10.03 (s, $1 \mathrm{H}, \mathrm{NHCO}) ;{ }^{13} \mathrm{C}$ NMR (DMSO- $d_{6}, 100 \mathrm{MHz}$ ) $\delta$ ppm: $21.45\left(6-\mathrm{CH}_{3}\right), 22.10\left(5-\mathrm{CH}_{3}\right), 22.30\left(3-\mathrm{CH}_{3}\right)$, $119.49,120.41,129.63,129.83,137.52,138.07,148.63$, $149.62,164.29(\mathrm{C}=\mathrm{O}), 169.50(\mathrm{C}=\mathrm{O})$.

N-(3-(Hydroxycarbamoyl)phenyl)-3,5,6-Trimethylpyrazine2-Carboxamide (8a)

Yield $52 \%$, m.p. $>250^{\circ} \mathrm{C} ;{ }^{1} \mathrm{H}$ NMR (DMSO- $d_{6}, 400 \mathrm{MHz}$ ) $\delta$ ppm: 2.51 (s, 3H, 6- $\left.\mathrm{CH}_{3}\right), 2.55$ (s, 3H, 5- $\left.\mathrm{CH}_{3}\right), 2.72(\mathrm{~s}, 3 \mathrm{H}$, $\left.3-\mathrm{CH}_{3}\right), 7.72(\mathrm{~s}, 1 \mathrm{H}, \mathrm{NHOH}), 7.18-7.76(\mathrm{~m}, 4 \mathrm{H}, \mathrm{Ar}-\mathrm{H}), 9.10$ (s, $1 \mathrm{H}, \mathrm{NHOH}), 10.36(\mathrm{~s}, 1 \mathrm{H}, \mathrm{NHCO})$.

N-(3-(Hydrazinecarbonyl)phenyl)-3,5,6-Trimethylpyrazine2-Carboxamide (8b)

Yield $45 \%$, m.p. $>250{ }^{\circ} \mathrm{C} ;{ }^{1} \mathrm{H}$ NMR (DMSO- $d_{6}, 400 \mathrm{MHz}$ ) $\delta$ ppm: $2.50-252\left(3,9 \mathrm{H}, 3\left(\mathrm{CH}_{3}\right)\right), 4.49\left(\mathrm{~s}, 2 \mathrm{H}, \mathrm{NH}_{2}\right), 7.35-7.87$ (m, 4H, Ar-H), 8.81 (s, 1H, $\left.\mathrm{NHNH}_{2}\right), 9.69$ (s, 1H, NHCO).

\section{Biological Evaluations Evaluation of Inhibitory Activity Against HDACI and HDAC2}

All the newly synthesized ligustrazine-based derivatives (7a-c and 8a,b) were evaluated for their potential inhibitory activity toward $\mathrm{HDAC} 1$ and $\mathrm{HDAC} 2$ as the following. Ten microliters of diluted Trichostatin A was added to two of the positive control wells and to two of each of the sample wells. Trichostatin A eliminated all HDAC activity and was used as a control for generating the sample background values. $10 \mu \mathrm{L}$ of diluted Assay Buffer was added to the positive control and sample wells that were not treated with Trichostatin A. Reactions were initiated after the addition of 
$10 \mu \mathrm{L}$ of HDAC substrate to all the wells being used including the standard wells. The final concentration of substrate was $200 \mu \mathrm{M}$ in the wells. The plate was covered and incubated on a shaker for $30 \mathrm{~min}$ at $37^{\circ} \mathrm{C}$. Then, the plate cover was removed and $40 \mu \mathrm{L}$ of developer was added and incubated for $15 \mathrm{~min}$ at room temperature. ${ }^{23}$ Fluorescence was measured by spectrophotometry at an excitation wavelength of 340-360 $\mathrm{nm}$ and an emission wavelength of $440-465 \mathrm{~nm}$. The average fluorescence of the Trichostatin-treated samples were subtracted from the average fluorescence of its corresponding samples to yield the corrected sample fluorescence (CSF). Finally, the HDAC activity was calculated using the following equation: HDAC Activity $(\mathrm{nmol} / \mathrm{min} / \mathrm{mL})=[\mu \mathrm{M} / 30 \mathrm{~min}] \times$ sample dilution. One unit is defined as the amount of enzyme that caused the formation of $1.0 \mathrm{nmol}$ of deacetylated compound per minute at $37^{\circ} \mathrm{C}$.

\section{In vitro Antiproliferative Activity}

Ligustrazine-based derivatives (7a-c and $\mathbf{8 a}, \mathbf{b}$ ) were evaluated for their antiproliferative potency toward colorectal (HT-29) and neuroblastoma (SH-SY5Y) cancer cell lines. Both cell lines were obtained from American Type Culture Collection (ATCC). Cells were cultured using DMEM (Invitrogen, Life Technologies) supplemented with 10\% FBS (Hyclone), $10 \mathrm{ug} /$ $\mathrm{mL}$ of insulin (Sigma), and 1\% penicillin-streptomycin. All of the other chemicals and reagents were from Sigma, or Invitrogen. Plate cells (cell density: $1.2-1.8 \times 10^{4} /$ well) in a volume of $100-\mu \mathrm{L}$ complete growth medium $+100 \mu \mathrm{L}$ of the tested compound per well in a 96-well plate for $24 \mathrm{~h}$ before the assay. Antiproliferative activity of compounds (7a-c and 8a,b) was evaluated following the protocol of MTT (3-[4,5-dimethylthiazol-2-yl]-2,5-diphenyltetrazolium bromide) reduction assay, as reported previously. ${ }^{24-26}$

\section{Molecular Docking}

All molecular docking simulations were performed in the molecular operating environment (MOE). ${ }^{27}$ The crystal structures of HDAC1 and HDAC2 (PDB ID: 4BKX and 6G3O, respectively) were downloaded from the RCSB Protein Data Bank. The structures were chosen based on crystal structure resolution and 2D similarity of the co-crystallized ligand to the target compounds. Prior to docking simulations, the proteins were prepared according to the following protocol. All water molecules and ligands were removed, except for the $\mathrm{Zn}$ ion. Afterward, the hydrogen atoms were added and the protein structure was protonated using the Protonate $3 \mathrm{D}$ tool at a temperature of $300 \mathrm{~K}, \mathrm{pH}$ of 7.0 and ion concentration of
$0.1 \mathrm{~mol} / \mathrm{L}$. The Site Finder tool was used to determine the protein-ligand binding site, which included 19 residues of the ligand-binding pocket. The 2D structures of the ligustrazinebased derivatives (7a-c and 8a,b) and their tautomers were constructed using the Builder tool and energy minimized under the MMFF94x force field and 0.05 rmsd gradient.

The docking protocol included several steps. The first placement of the generated 3D conformations in the protein active site was done by the Triangle Matcher placement method. The favorability of the generated poses was scored by the London dG scoring function, which estimated the binding free energy of the ligand from a given pose. The 30 best-scoring poses underwent further refinement by the MMFF94x force field minimization and subsequent re-scoring by the Affinity dG scoring function. The final poses were evaluated according to the Affinity $\mathrm{dG}$ docking score (S), which estimates the enthalpic contribution to ligand-binding free energy as a sum of the hydrogen bond, ionic, metal ligation, hydrophobic and Van der Waals favorable interactions and unfavorable interactions between polar and hydrophobic atoms.

The docking method was verified by performing redocking of the co-crystallized squaramide inhibitor ${ }^{28}$ from the HDAC2 structure (PDB ID: 6G3O). Under given docking parameters, the predicted dock pose retained the key interactions from the initial crystal structure (Figure 2), and heavy atom RMSD between the co-crystal and dock pose was $0.8784 \AA$, with most of the deviations occurring in the solvent-exposed region of the binding site.

\section{Result and Discussion}

\section{Chemistry}

The synthetic pathway adopted for the preparation of the key intermediates and target ligustrazine-based HDACIs (7a-c and $\mathbf{8 a}, \mathbf{b})$ is depicted in Scheme 1. Synthesis was initiated by oxidation of ligustrazine 1 with hot $\mathrm{KMnO}_{4}$ solution to afford 3,5,6-trimethylpyrazine-2-carboxylic acid $2 .{ }^{19}$ Then, carboxylic acid 2 underwent coupling with $p$-aminobenzoic acid 3a, $p$-aminophenylacetic acid $3 \mathrm{~b}$, and $m$-aminobenzoic acid 4 via 1 '-carbonyldiimidazole (CDI) to furnish the key intermediates $\mathbf{4 a}, \mathbf{b}$ and $\mathbf{6}$, respectively. Then, the target ligustrazinebased HDACIs (7a-c and 8a, b) were obtained, with 45-60\% yield, via coupling of key intermediates $\mathbf{4 a , b}$ and $\mathbf{6}$ with hydrazine hydrate or hydroxylamine by the use of CDI (Scheme 1).

HNMR spectra of $7 \mathbf{a}$ and $\mathbf{7 c}$, and $\mathbf{8 b}$ showed new peaks at $\delta 4.53,4.39$ and 4.49 , respectively, equivalent to $\mathrm{NH}_{2}$ protons 


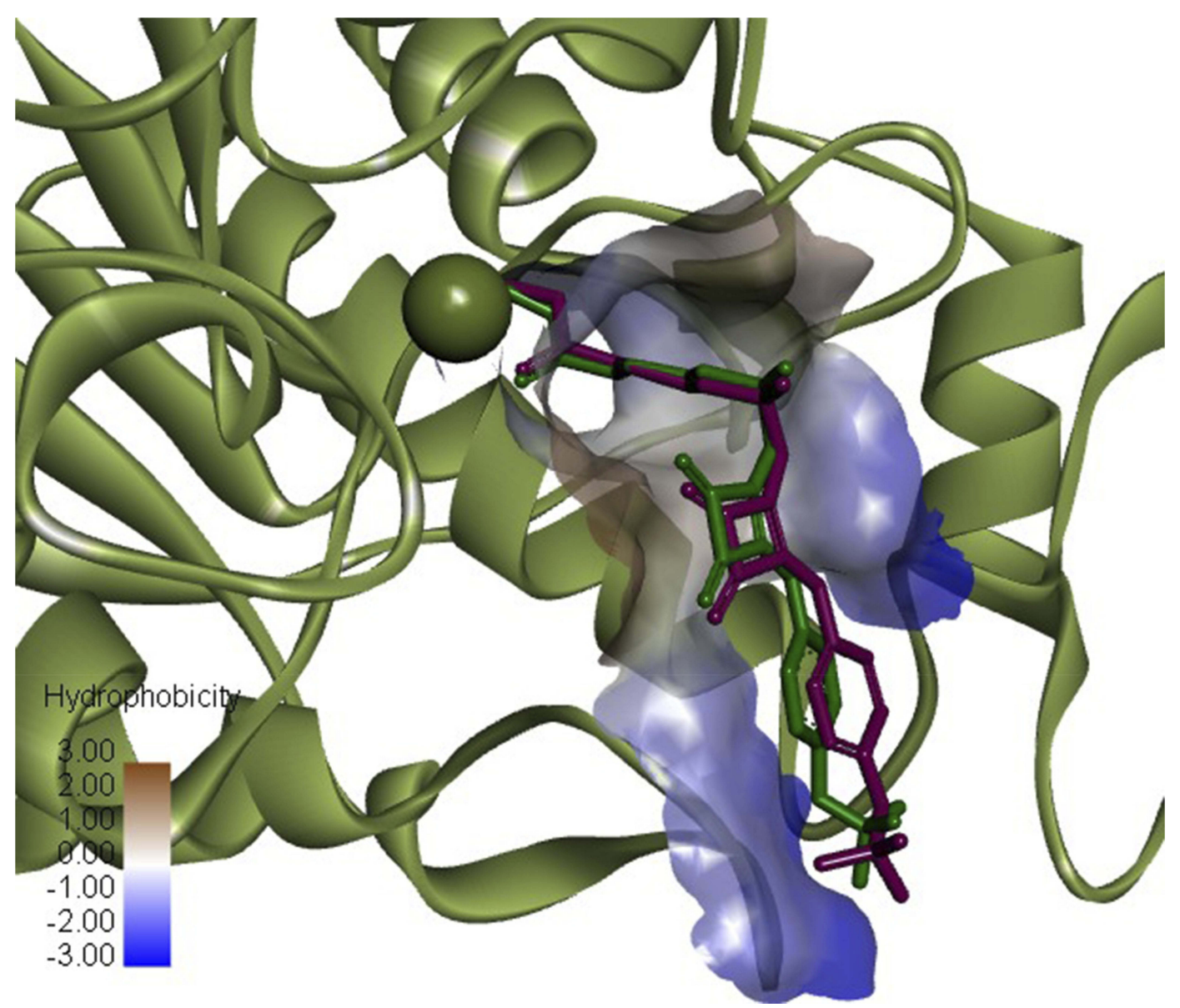

Figure 2 Superimposition of HADC2 inhibitor co-crystal conformation (green) and predicted dock conformation (purple). Zn atom showed as green sphere (PDB ID: 6G3O). Image prepared in Discovery Studio Visualizer.

but at $\delta 9.67,9.12$ and 8.81 represent $\mathrm{NHNH}_{2}$ consequently. The characteristic $\mathrm{OH}$ peak of $\mathbf{7 c}$ and $\mathbf{8 a}$ appeared down filed at $\delta 10.58$ and 9.10 , respectively. New other $\mathrm{NH}(\mathrm{NHOH})$ peaks of $\mathbf{7 b}$ and $\mathbf{8 b}$ appeared at $\delta 7.08$ and 7.72, respectively. The mentioned new HNMR peaks confirmed the structure of $7 \mathbf{a}-\mathbf{c}$ and $8 \mathrm{a}$ and $\mathbf{b}$, and reactional conversion of $\mathbf{4 a}$ and $\mathbf{b}$ to $7 \mathbf{a}-\mathbf{c}$ and 6 to $8 \mathbf{a}$ and $\mathbf{b}$.

\section{Biological Evaluation \\ Evaluation of Inhibitory Activity Against HDACl and HDAC2}

All the newly synthesized ligustrazine-based derivatives (7a-c and 8a,b) were evaluated for their potential inhibitory activity toward HDAC1 as well as toward HDAC2. The inhibitory activities were compared to Dacinostat, a clinically used standard HDAC inhibitor. Table 1 displays the half-maximal inhibitory concentration data $\left(\mathrm{IC}_{50}\right.$ values) for the examined compounds and Dacinostat towards HDAC1 and HDAC2.
The data displayed in Table 1 showed excellent to weak inhibitory activities against both HDAC1 and HDAC2. Investigation of the obtained $\mathrm{IC}_{50}$ values revealed that the tested ligustrazine-based compounds were more potent toward HDAC2 ( $\mathrm{IC}_{50}$ range: 53.7-205.4 $\mathrm{nM}$ ) than HDAC1 ( $\mathrm{IC}_{50}$ range: 114.3-2434.7 $\left.\mathrm{nM}\right)$. In particular, compound 7a was found to be the most potent analog in this study toward HDAC1 and HDAC2 with $\mathrm{IC}_{50}$ values equal 114.3 and $53.7 \mathrm{nM}$, respectively. In addition, compounds $\mathbf{7 b}$ and $\mathbf{8 b}$ displayed more potent HDAC2 inhibitory activity $\left(\mathrm{IC}_{50}=112.9\right.$ and $132.3 \mathrm{nM}$, respectively) than the standard drug Dacinostat $\left(\mathrm{IC}_{50}=\right.$ $112.86 \mathrm{nM})$. On the other hand, compounds 7c and 8a showed moderate inhibitory activity toward HDAC1 with $\mathrm{IC}_{50}=263.5$ and $468.1 \mathrm{nM}$, respectively, whereas, compounds $\mathbf{7 b}$ and $\mathbf{8 b}$ exhibited weak HDAC1 inhibitory activity $\left(\mathrm{IC}_{50}=2434.7\right.$ and $1800.1 \mathrm{nM}$, respectively)

It is noteworthy that shifting of hydrazide ZBG from para (7a) to meta $(\mathbf{8 b})$ position resulted in a 15.7-fold and 2.1-fold 
<smiles>Cc1nc(C)c(C(=O)O)nc1C</smiles>

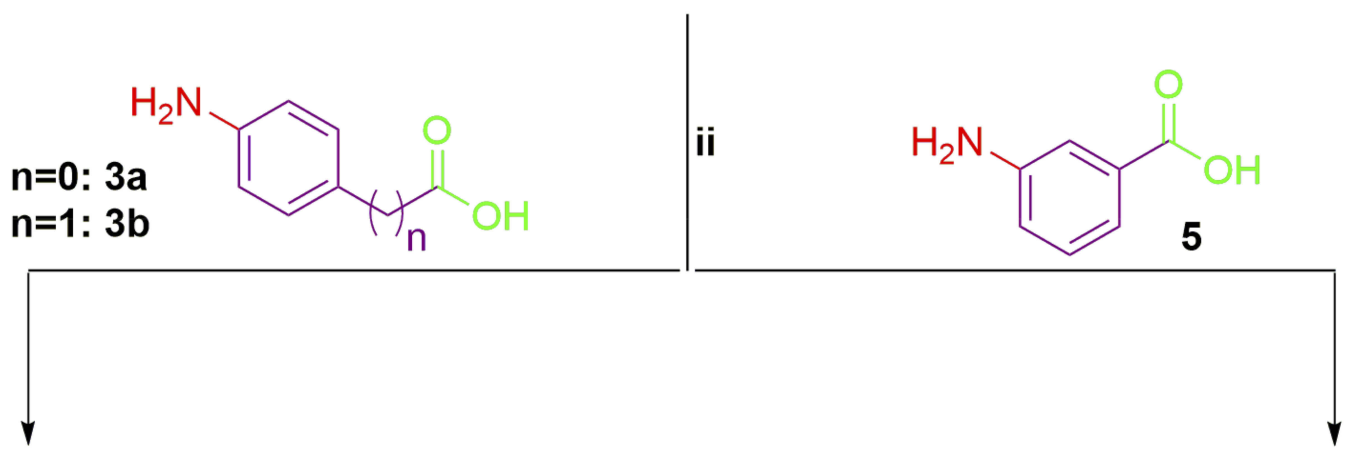<smiles>Cc1nc(C)c(C(=O)Nc2ccc(C(=O)C(=O)O)cc2)nc1C</smiles>

$\mathrm{n}=0: 4 a$

$n=1: 4 b$

iii<smiles>NN</smiles><smiles>Cc1nc(C)c(C(=O)Nc2cccc(C(=O)O)c2)nc1C</smiles>

6<smiles>N[V][V]</smiles><smiles>[Y]NC(=O)C(=C)c1ccc(NC(=O)c2nc(C)c(C)nc2C)cc1</smiles>

$\mathrm{X}=\mathrm{NH}, \mathrm{n}=0: 7 \mathrm{a}$

$X=0, n=1: 7 b$ $\mathrm{X}=\mathrm{NH}, \mathrm{n}=1: 7 \mathrm{c}$<smiles>[Y]NC(=O)c1cccc(NC(=O)c2nc(C)c(C)nc2C)c1</smiles>

$X=0: 8 a$

$\mathrm{X}=\mathrm{NH}: \mathbf{8 b}$

Scheme I Synthesis of target HDAC inhibitors $\mathbf{7 a - c}$ and $\mathbf{8 a}$,b; Reagents and conditions: (i) $\mathrm{KMnO}_{4}$ solution, heating $50^{\circ} \mathrm{C} 12$ h, (ii) $\mathrm{CDI}$, THF, r.t. 2 h, then TFA, r.t. 10 h, (iii) $\mathrm{THF}, \mathrm{CDI}, 60^{\circ} \mathrm{C} 6 \mathrm{~h}$.

worsening of effectiveness against HDAC1 and HDAC2, respectively. Analogously, extending the hydrophobic spacer from phenyl (7a) to benzyl (7c) moiety resulted in a reduced inhibitory activity toward both HDAC1 and HDAC2.

\section{In vitro Antiproliferative Activity}

Ligustrazine-based derivatives (7a-c and $\mathbf{8 a}, \mathbf{b}$ ) were evaluated for their antiproliferative potency toward two
HDAC-expressing cancer cell lines; ${ }^{29,30}$ colorectal (HT29) and neuroblastoma (SH-SY5Y) cell lines, utilizing the 3-(4,5-dimethylthiazol-2-yl)-2,5-diphenyltetrazolium bromide (MTT) colorimetric assay [24]. The clinically used anticancer drug Gefitinib was co-assayed as a reference drug. The growth inhibitory activities of the tested ligustrazine-based derivatives against the two cancer cell lines were measured as $\mathrm{IC}_{50}$ values $(\mu \mathrm{M})$, which 
Table I HDACI and HDAC2 Inhibitory Activities of the Newly Synthesized Ligustrazine-Based Derivatives 7a-7c and 8a, b

\begin{tabular}{|l|l|l|}
\hline \multirow{2}{*}{ Compound } & \multicolumn{2}{|l|}{ IC 5 (nM) } \\
\cline { 2 - 3 } & HDACI & HDAC2 \\
\hline $7 \mathrm{a}$ & $114.3 \pm 0.44$ & $53.7 \pm 0.05$ \\
$7 \mathrm{~b}$ & $2434.7 \pm 1.25$ & $132.3 \pm 0.12$ \\
$7 \mathrm{c}$ & $263.5 \pm 1.27$ & $205.4 \pm 0.43$ \\
$8 \mathrm{a}$ & $468.1 \pm 0.08$ & $168.8 \pm 0.13$ \\
$8 \mathrm{~b}$ & $1800.1 \pm 0.45$ & $112.9 \pm 0.09$ \\
Dacinostat & $129.4 \pm 0.07$ & $136.3 \pm 0.11$ \\
\hline
\end{tabular}

Note: Data were expressed as mean \pm standard error (S.E.) of three independen experiments.

represent the compound concentration required to produce a $50 \%$ inhibition of cell growth after $48 \mathrm{~h}$ of incubation, compared to untreated controls, and listed in Table 2.

Investigations of the results of the MTT assay highlighted that the tested ligustrazine-based derivatives (7a-c and $\mathbf{8 a}, \mathbf{b}$ ) were more effective toward colorectal HT-29 cells than neuroblastoma SH-SY5Y cells, except compound 7a which possessed much enhanced growth inhibitory activity against SH-SY5Y $\left(\mathrm{IC}_{50}=1.60 \pm 0.04 \mu \mathrm{M}\right)$ than HT-29 cells $\left(\mathrm{IC}_{50}=15.10 \pm 0.43 \mu \mathrm{M}\right)$. Regarding the antiproliferative activity against colorectal HT-29 cells, compound 8a $\left(\mathrm{IC}_{50}=1.96 \pm 0.05 \mu \mathrm{M}\right)$ was found to be the most active member in this study, being 2.5-times more potent than reference drug Gefitinib $\left(\mathrm{IC}_{50}=4.99\right.$ $\pm 0.14 \mu \mathrm{M})$. Also, compounds $\mathbf{7 b}$ and $\mathbf{8 b}$ displayed higher antiproliferative activities $\left(\mathrm{IC}_{50}=4.57 \pm 0.13\right.$ and 3.25 $\pm 0.09 \mu \mathrm{M}$, respectively) than reference drug Gefitinib in HT-29 cell line.

On the other hand, exploring the antiproliferative activity toward neuroblastoma SH-SY5Y cells revealed that compound 7a was the most effective counterpart $\left(\mathrm{IC}_{50}=1.60\right.$

Table 2 In vitro Antiproliferative Activities of Compounds 7a-7c and 8a, b Against HT-29 and SH-SY5Y Cancer Cell Lines

\begin{tabular}{|l|l|l|}
\hline \multirow{2}{*}{ Compound } & \multicolumn{2}{|l|}{ IC $\mathbf{5 0}(\mu \mathrm{M})$} \\
\cline { 2 - 3 } & HT-29 & SH-SY5Y \\
\hline $\mathbf{7 a}$ & $15.10 \pm 0.43$ & $1.60 \pm 0.04$ \\
$\mathbf{7 b}$ & $4.57 \pm 0.13$ & $67.00 \pm 1.91$ \\
$\mathbf{7 c}$ & $6.11 \pm 0.17$ & $43.45 \pm 1.21$ \\
$\mathbf{8 a}$ & $1.96 \pm 0.05$ & $4.27 \pm 0.12$ \\
$\mathbf{8 b}$ & $3.25 \pm 0.09$ & $28.50 \pm 0.8$ \\
Gefitinib & $4.99 \pm 0.14$ & $7.63 \pm 0.21$ \\
\hline
\end{tabular}

Note: $I_{50}$ values are the mean $\pm S D$ of three separate experiments. $\pm 0.04 \mu \mathrm{M}$ ), with 4.7 -fold enhanced efficiency than Gefitinib $\left(\mathrm{IC}_{50}=7.63 \pm 0.21 \mu \mathrm{M}\right)$ against SH-SY5Y cells. Moreover, compound 8a possesses higher activity to Gefitinib with $\mathrm{IC}_{50}=4.27 \pm 0.12 \mu \mathrm{M}$. Whereas, compounds $\mathbf{7 b}, \mathbf{7 c}$ and $\mathbf{8 b}$ displayed moderate growth inhibitory activity toward SHSY5Y with $\mathrm{IC}_{50}$ values equal $4.57 \pm 0.13,6.11 \pm 0.17$ and 3.25 $\pm 0.09 \mu \mathrm{M}$, respectively.

\section{Molecular Modeling}

Comparison of HDACl and HDAC2 Sequences and Structure Overlap

The sequences of HDAC1 and HDAC2 are highly conserved (sequence identity: $93.8 \%$ and sequence similarity: 98.1\%). Within $8 \AA$ radius from the center of the active site, there is only 1 sequence difference: Ser263 (HDAC1) vs Ala268 (HDAC2), which does not cause significant structural changes in the backbone position of active site residues. Most structural deviation occurs in residues Asp104, His146, Phe155, His183, Tyr209, Phe210 according to HDAC2 numbering. Three-dimensional figures viewed from different angles (A,B, C) were grouped and depicted clearly in Figure 3. The resolution of the HDAC1 crystal structure ( $3 \AA$ ) is a limitation that does not allow comparing the structures with full confidence.

\section{Molecular Docking Studies}

The binding orientations of the ligustrazine-based derivatives (7a-c and $\mathbf{8 a}, \mathbf{b})$ and their possible tautomeric forms were predicted using MOE under default docking placement parameters, followed by the force field pose refinement stage and re-scoring by the Affinity $\mathrm{dG}$ scoring function. The capability of the chosen docking protocol to correctly rank the compounds by their binding affinity (scoring power) is illustrated in Figure 4. In the cases of both HDAC1 and HDAC2 docking, the most and least potent compounds were correctly ranked with sufficient difference in dock score (S). The overall correlation coefficient $\mathrm{R}^{2}$ (0.61 and 0.74 for HDAC1 and HDAC2, respectively) is as well- or higher-performing than the recent evaluation of scoring power done by Huo et $\mathrm{al}^{31}$ on a diverse set of protein-ligand complexes for 10 commercially available and academic docking programs. Together with the ability to correctly reproduce the binding pose of the known squaramide inhibitor (see details in Methods section), these findings indicate that the generated 3D ligand binding poses are trustworthy and can be used to explain the true protein-ligand binding interactions. The dock scores (S) and a list of the highly contributing 

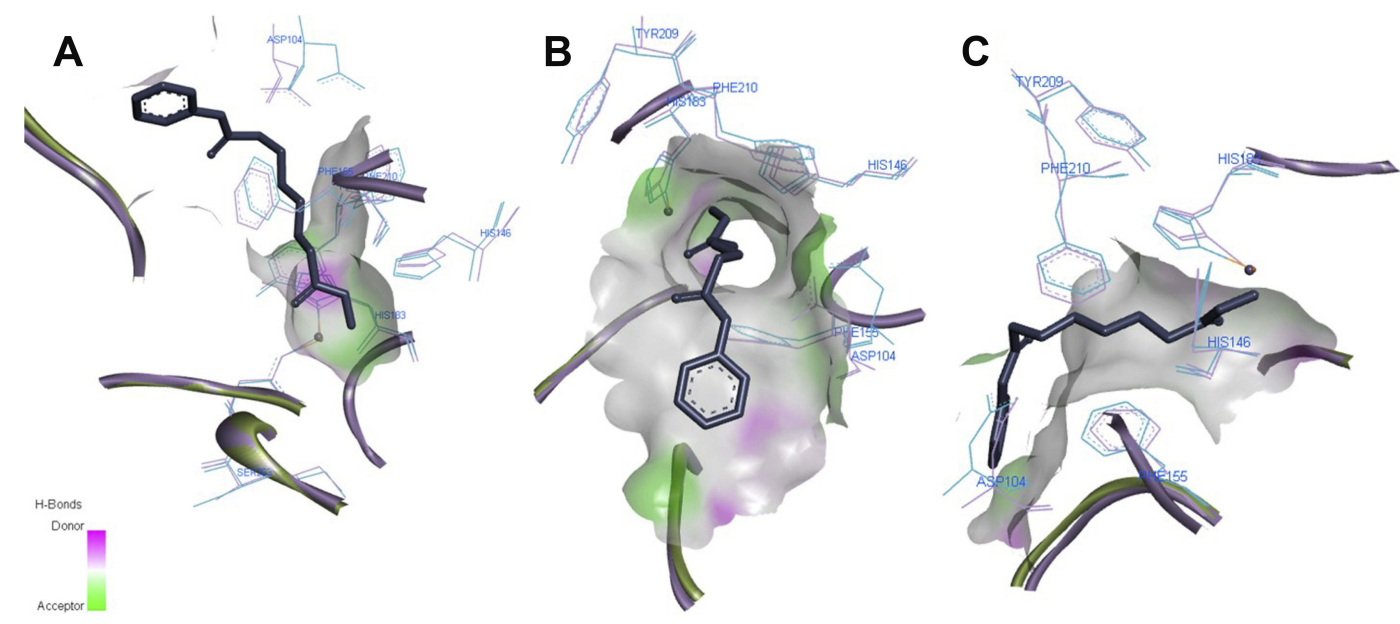

Figure 3 Comparison of HDACI (blue) and HDAC2 (purple) structures from different angles (A-C). Residues are labeled according to HDAC2 numbering, co-crystal ligand represented in stick view, Zn atom - as red bead. Images prepared in Discovery Studio Visualizer.

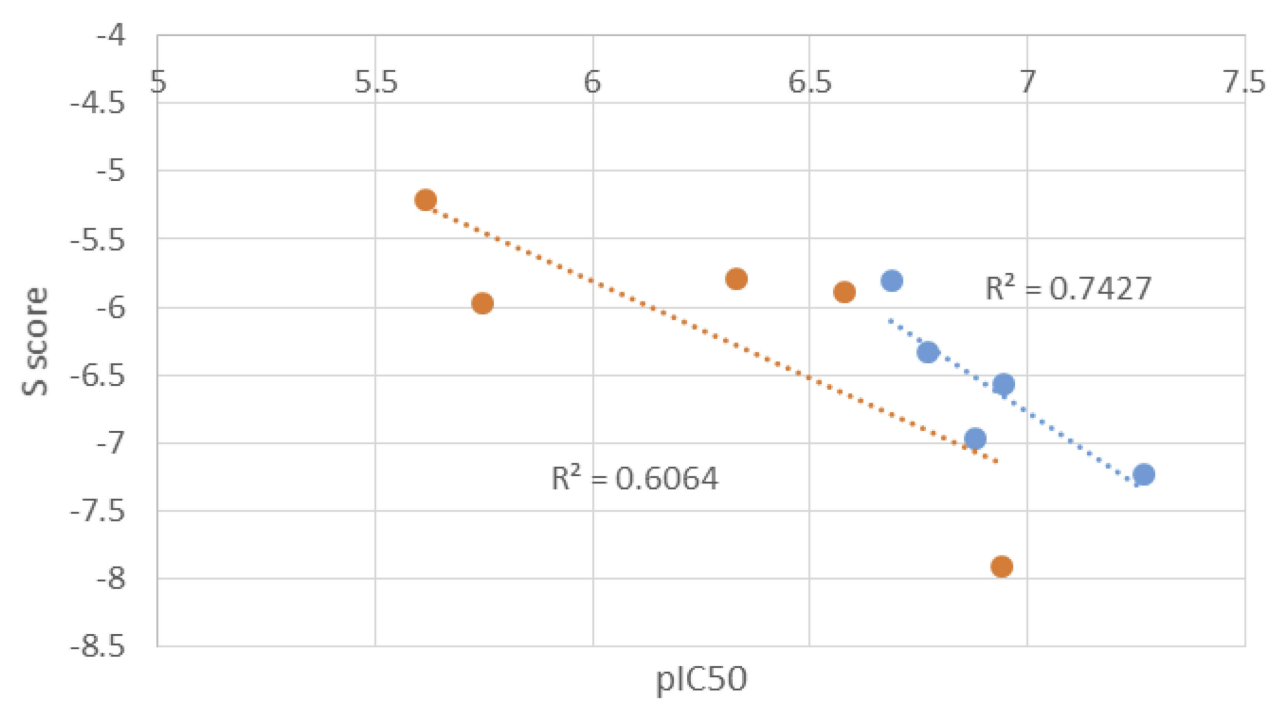

HDAC2 OHDAC1

Figure 4 Correlation between $\mathrm{plC}_{50}$ and $\mathrm{S}$ Score for target compounds in HDACl and HDAC2.

interactions of the ZBG for each of the ligustrazine-based derivatives (7a-c and $\mathbf{8 a}, \mathbf{b}$ ) are presented in Tables 3 and 4 .

The most active compound $7 \mathbf{a}$ demonstrated the best binding affinity with $\mathrm{S}$ equal -7.2309 (HDAC2) and -7.9092 (HDAC1) with similar dock poses in both proteins (Figure 5). The ZBG of 7a makes several strong ionic interactions with $\mathrm{Zn}^{2+}$ ion, as well as numerous H-bonds with His145, His183, Tyr308, and Asp181 residues. The phenyl linker group is sandwiched between 3 aromatic residues Phe155, His183 and Phe210 by pi-pi stacking interactions. The ligustrazine cap moiety and amide linker are capable of pinching the Asp104 via a pication and $\mathrm{H}$-bond, respectively, thus resembling the known squaramide HDAC2 inhibitor.

The docking pose and binding interactions of compounds $\mathbf{7 b}, \mathbf{7} \mathbf{c}, \mathbf{8 a}$, and $\mathbf{8 b}$ in HDAC2 are similar to that of $7 \mathbf{a}$; however, they have less favorable interactions and lower dock scores, indicating a lower value of the free energy of binding for these compounds (Table 4). Generally, hydrazine ZBG-based derivatives show stronger ionic binding interactions, 
Table 3 Docking Results and Characteristic of the Strongest Interactions of ZBG of Target Compounds Within HDACI

\begin{tabular}{|c|c|c|c|c|c|}
\hline \multirow[t]{2}{*}{ Compound } & \multicolumn{5}{|l|}{ HDACI } \\
\hline & $I C_{50}(n M)$ & Docking Score (S) & Bonding Interaction & Bond Length & Bond Type \\
\hline $7 a$ & II 4.3286 & -7.9092 & $\begin{array}{l}\text { Zn } \\
\text { His I } 40 \\
\text { Tyr308 }\end{array}$ & $\begin{array}{l}1.95 \\
3.14 \\
2.63\end{array}$ & $\begin{array}{l}\text { lonic } \\
\text { H-donor } \\
\text { H-donor }\end{array}$ \\
\hline $7 b$ & 2434.738 & -5.2063 & $\begin{array}{l}\text { Zn } \\
\text { Gly|49 } \\
\text { His I78 }\end{array}$ & $\begin{array}{l}2.28 \\
1.84 \\
2.69\end{array}$ & $\begin{array}{l}\text { lonic } \\
\mathrm{H} \text {-donor } \\
\mathrm{H} \text {-acceptor }\end{array}$ \\
\hline 7c & 263.5337 & -5.8862 & $\begin{array}{l}\text { Zn } \\
\text { Asp I76 } \\
\text { His I78 }\end{array}$ & $\begin{array}{l}1.93 \\
1.96 \\
2.28\end{array}$ & $\begin{array}{l}\text { lonic } \\
\text { lonic } \\
\text { lonic }\end{array}$ \\
\hline $8 \mathbf{a}$ & 468.1426 & -5.7948 & $\begin{array}{l}\text { Zn } \\
\text { Aspl76 } \\
\text { His I4I }\end{array}$ & $\begin{array}{l}2.49 \\
1.96 \\
2.33\end{array}$ & $\begin{array}{l}\text { Ionic } \\
\text { lonic } \\
\text { H-donor }\end{array}$ \\
\hline $8 \mathbf{b}$ & 1800.053 & $-5.997 \mid$ & $\begin{array}{l}\text { Zn } \\
\text { Aspl76 } \\
\text { His I78 }\end{array}$ & $\begin{array}{l}1.86 \\
1.95 \\
2.28\end{array}$ & $\begin{array}{l}\text { lonic } \\
\text { lonic } \\
\text { lonic }\end{array}$ \\
\hline
\end{tabular}

Table 4 Docking Results and Characteristic of the Strongest Interactions of ZBG of Target Compounds Within HDAC2

\begin{tabular}{|c|c|c|c|c|c|}
\hline \multirow[t]{2}{*}{ Compound } & \multicolumn{5}{|l|}{ HDAC2 } \\
\hline & $\mathrm{IC}_{50}(\mathrm{nM})$ & Docking Score (S) & Bonding Interaction & Bond Length & Bond Type \\
\hline $7 a$ & 53.70386 & -7.2309 & $\begin{array}{l}\text { Zn } \\
\text { HisI45 } \\
\text { Tyr308 }\end{array}$ & $\begin{array}{l}1.86 \\
3.2 \\
2.66\end{array}$ & $\begin{array}{l}\text { lonic } \\
\text { H-donor } \\
\text { H-donor }\end{array}$ \\
\hline $7 \mathbf{b}$ & 132.273 & -6.9653 & $\begin{array}{l}\text { Zn } \\
\text { His I45 } \\
\text { Aspl8I }\end{array}$ & $\begin{array}{l}2.05 \\
2.6 \\
1.97\end{array}$ & $\begin{array}{l}\text { lonic } \\
\text { H-donor } \\
\text { lonic }\end{array}$ \\
\hline 7c & 205.3559 & -5.8036 & $\begin{array}{l}Z n \\
\text { Aspl8I } \\
\text { Tyr308 }\end{array}$ & $\begin{array}{l}1.83 \\
1.97 \\
2.73\end{array}$ & $\begin{array}{l}\text { lonic } \\
\text { lonic } \\
\mathrm{H} \text {-acceptor }\end{array}$ \\
\hline $8 a$ & $|68.780|$ & -6.3261 & $\begin{array}{l}Z n \\
\text { Aspl8I } \\
\text { His I46 }\end{array}$ & $\begin{array}{l}2.29 \\
1.97 \\
2.84\end{array}$ & $\begin{array}{l}\text { lonic } \\
\text { lonic } \\
\text { H-donor }\end{array}$ \\
\hline $8 b$ & || $2.858 \mid$ & -6.5720 & $\begin{array}{l}\text { Zn } \\
\text { Tyr308 } \\
\text { Asp I8I }\end{array}$ & $\begin{array}{l}1.89 \\
2.81 \\
1.97\end{array}$ & $\begin{array}{l}\text { lonic } \\
\mathrm{H} \text {-acceptor } \\
\text { lonic }\end{array}$ \\
\hline
\end{tabular}

as well as the dock scores are higher for parasubstituted aryl linker derivatives.

The comparison of the 3D ligand docking poses provides a possible explanation for the selectivity of $\mathbf{7 b}$ for HDAC2 over HDAC1 and the corresponding decrease in the estimated free binding energy. Although the sequences of HDAC1 and HDAC2 are highly conserved, the slight differences in the published crystal structures resulted in the $3 \mathrm{D}$ ligand binding poses of $\mathbf{7 a}, \mathbf{7 b}$, and $7 \mathbf{c}$ compounds to show different patterns when overlapped (Figure 6). In HDAC2, the complex of interactions with $\mathrm{Zn}^{2+}$ ion is maintained by all three compounds, and the decrease of docking score is small, coming from slightly less favorable hydrophobic interactions. Whereas in HDAC1, the most 

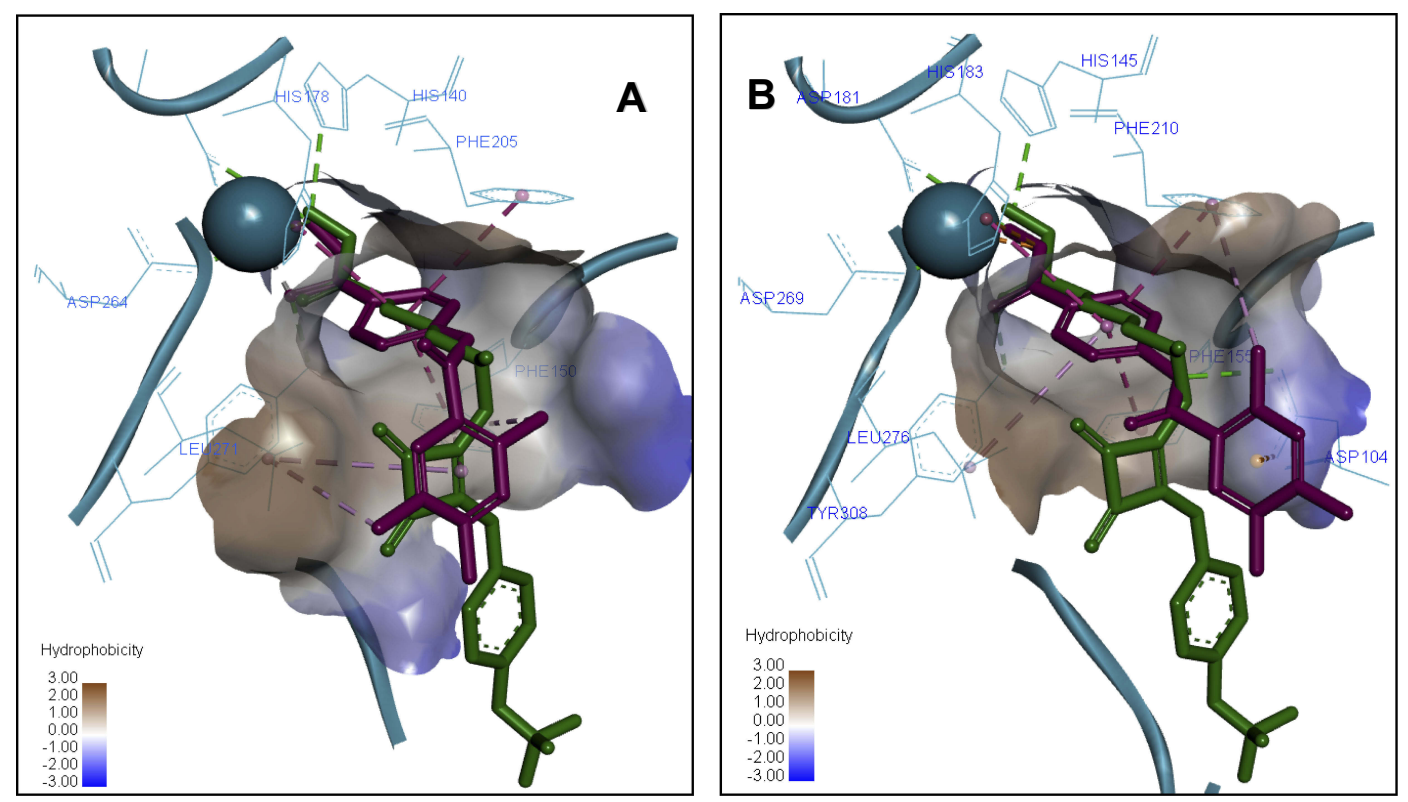

Figure 5 Predicted 3D ligand binding pose of compound 7a (purple) in the HDACI (A) and HDAC2 (B) active sites overlapped with the binding pose of a known HDAC inhibitor from crystal structure 6G3O (green). The interacting residues are shown in line view, $\mathrm{Zn}$ ion is shown as a sky blue sphere. Dotted lines are used to visualize the protein-ligand interactions. Image prepared in Discovery Studio Visualizer.
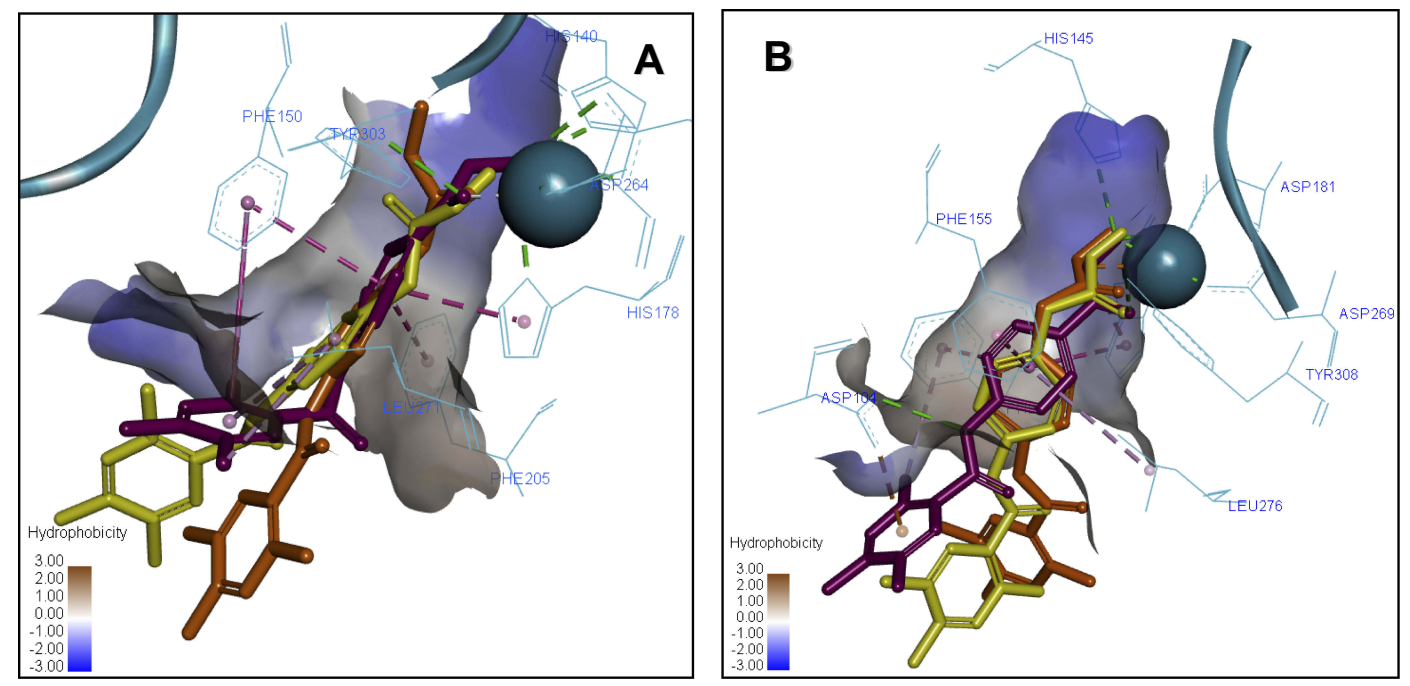

Figure 6 Overlay of the 3D ligand binding poses of compounds 7a (purple), 7b (orange) and 7c (yellow) in the HDACI (A) and HDAC2 (B) ligand-binding sites. The interacting residues are shown in line view, $\mathrm{Zn}$ ion is shown as a sky blue sphere. Dotted lines are used to visualize the protein-ligand interactions. Image prepared in Discovery Studio Visualizer.

favorable docking poses showed such a reorientation of the ligand in the binding site that the Pi-Pi stacking interactions with Phe155, His183, and Phe210 are conserved, but there is a significant loss in interactions of the ZBG, which is more critical for inhibitor potency.

A similar tendency appears when the 3D ligand binding poses for compounds 7a, 8a and $\mathbf{8 b}$ are overlapped (Figure 7). In the HDAC2 crystal structure, the ZBG orientation is well overlapped in the poses of 7a, 8a and 8b. Whereas in HDAC1, the docking results show that both $8 \mathbf{a}$ and $8 \mathbf{b}$ share the hydrophobic Pi-Pi stacking interactions of compound $\mathbf{7 a}$; however, both fail to repeat the same interactions of the ZBG, which results in a higher penalty for the docking score and possibly explains why the changes in inhibition potency for these compounds in HDAC1 and HDAC2 are different. 

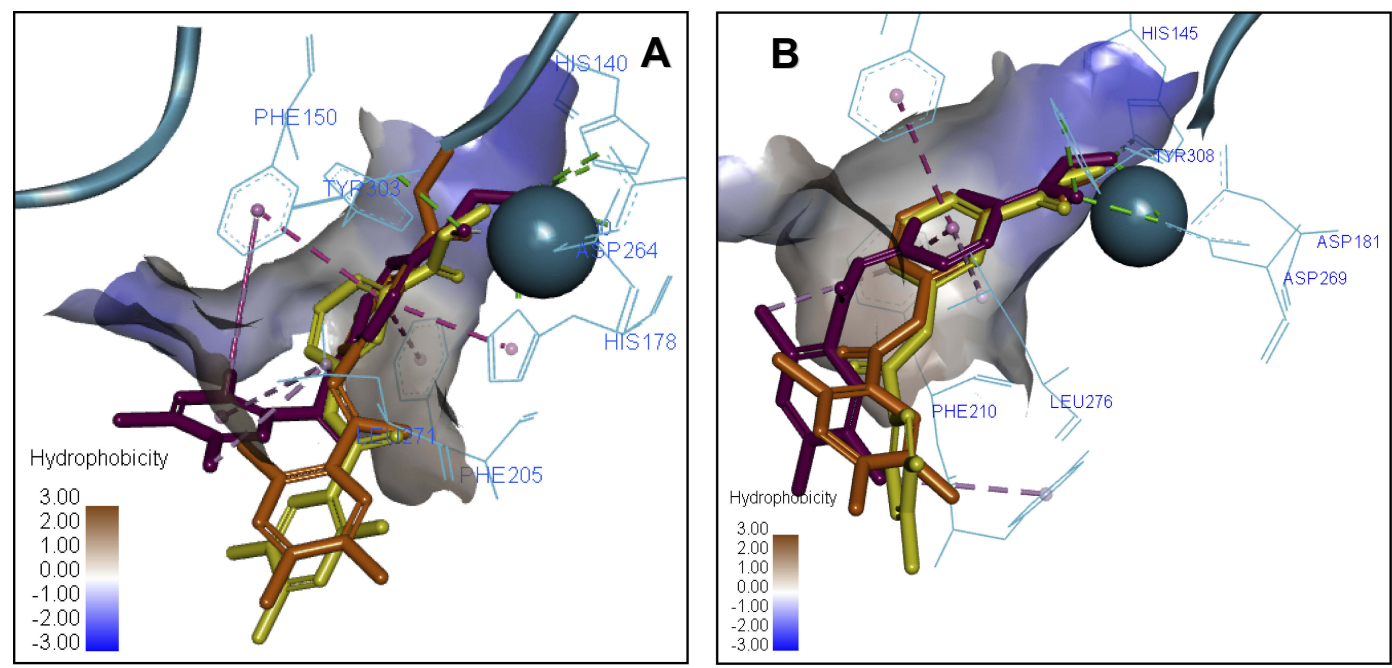

Figure 7 Overlay of the 3D ligand binding poses of compounds $\mathbf{7 a}$ (purple), 8a (orange) and $\mathbf{8 b}$ (yellow) in the HDACl (A) and HDAC2 (B) ligand-binding sites. The interacting residues are shown in line view, $\mathrm{Zn}$ ion is shown as a sky blue sphere. Dotted lines are used to visualize the protein-ligand interactions. Image prepared in Discovery Studio Visualizer.

\section{Conclusion}

In summary, herein we report the design and synthesis of a new set of HDAC inhibitors (7a-c and 8a, b) utilizing ligustrazine as a novel cap moiety. All the newly synthesized derivatives were evaluated for their potential inhibitory activity toward two class I histone deacetylases, namely HDAC1 and HDAC2. The tested ligustrazine-based compounds were more potent toward HDAC2 ( $\mathrm{IC}_{50}$ range: 53.7-205.4 nM) than HDAC1 $\left(\mathrm{IC}_{50}\right.$ range: $114.3-2434.7 \mathrm{nM})$. Compound $7 \mathbf{a}$ was found to be the most potent analog in this study toward HDAC1 and HDAC2 with $\mathrm{IC}_{50}$ values equal 114.3 and $53.7 \mathrm{nM}$, respectively. The SAR outcomes hinted that shifting of hydrazide ZBG from para (7a) to meta (8b) position resulted in a 15.7-fold and 2.1-fold worsening of effectiveness against HDAC1 and HDAC2, respectively. Analogously, extending the hydrophobic spacer from phenyl (7a) to benzyl (7c) moiety resulted in a reduced inhibitory activity toward both HDAC1 and HDAC2. Furthermore, the antiproliferative activities against two HDACexpressing cancer cell lines; HT-29 and SH-SY5Y were examined by the MTT assay. Compound 7a was the most effective molecule $\left(\mathrm{IC}_{50}=1.60 \mu \mathrm{M}\right)$, with 4.7-fold enhanced efficiency than reference drug Gefitinib $\left(\mathrm{IC}_{50}=7.63 \mu \mathrm{M}\right)$ against $\mathrm{SH}-$ SY5Y cells. Whereas, $8 \mathbf{8}\left(\mathrm{IC}_{50}=1.96 \mu \mathrm{M}\right)$ was the most active compound toward HT-29 cells, being 2.5-times more potent than Gefitinib $\left(\mathrm{IC}_{50}=4.99 \mu \mathrm{M}\right)$.

\section{Acknowledgments}

Korea Institute of Science and Technology (KIST) supported this research (2018 KIST School Partnership Research Grant).

\section{Disclosure}

The authors report no conflicts of interest in this work.

\section{References}

1. Kouzarides T. Chromatin modifications and their function. Cell. 2007;128(4):693-705. doi:10.1016/j.cell.2007.02.005

2. Luger K, Mäder AW, Richmond RK, Sargent DF, Richmond TJ. Crystal structure of the nucleosome core particle at $2.8 \AA$ resolution. Nature. 1997;389(6648):251. doi:10.1038/38444

3. Flaus A, Owen-Hughes T. Mechanisms for ATP-dependent chromatin remodelling: the means to the end. FEBS J. 2011;278(19):3579-3595. doi:10.1111/j.1742-4658.2011.08281.x

4. Al-Sanea M, Abdelazem A, Park B, et al. ROS1 kinase inhibitors for molecular-targeted therapies. Curr Med Chem. 2016;23(2):142-160. doi:10.2174/0929867322666151006093623

5. Abdelazem AZ, Al-Sanea MM, Park H-M, Lee SH. Synthesis of new diarylamides with pyrimidinyl pyridine scaffold and evaluation of their anti-proliferative effect on cancer cell lines. Bioorg Med Chem Lett. 2016;26(4):1301-1304. doi:10.1016/j.bmcl.2016. 01.014

6. Johnstone RW. Histone-deacetylase inhibitors: novel drugs for the treatment of cancer. Nat Rev Drug Discovery. 2002;1(4):287. doi:10.1038/ $\operatorname{nrd} 772$

7. Mai A, Massa S, Rotili D, et al. Histone deacetylation in epigenetics: an attractive target for anticancer therapy. Med Res Rev. 2005;25 (3):261-309. doi:10.1002/(ISSN)1098-1128

8. Zhang J, Zhong Q. Histone deacetylase inhibitors and cell death. Cell Mol Life Sci. 2014;71(20):3885-3901. doi:10.1007/s00018-0141656-6

9. Bertino EM, Otterson GA. Romidepsin: a novel histone deacetylase inhibitor for cancer. Expert Opin Investig Drugs. 2011;20 (8):1151-1158. doi:10.1517/13543784.2011.594437

10. Mann BS, Johnson JR, Cohen MH, Justice R, Pazdur R. FDA approval summary: vorinostat for treatment of advanced primary cutaneous T-cell lymphoma. Oncologist. 2007;12(10):1247-1252. doi:10.1634/theoncologist.12-10-1247

11. Laubach JP, Moreau P, San-Miguel JF, Richardson PG. Panobinostat for the treatment of multiple myeloma. Clin Cancer Res. 2015;21 (21):4767-4773. doi:10.1158/1078-0432.CCR-15-0530 
12. Lee H-Z, Kwitkowski VE, Del Valle PL, et al. FDA approval: belinostat for the treatment of patients with relapsed or refractory peripheral T-cell lymphoma. Clin Cancer Res. 2015;21 (12):2666-2670. doi:10.1158/1078-0432.CCR-14-3119

13. Lu X, Ning Z, Li Z, Cao H, Wang X. Development of chidamide for peripheral T-cell lymphoma, the first orphan drug approved in China. Intractable Rare Dis Res. 2016;5:185-191. doi:10.5582/irdr.2016. 01024

14. Zou J, Gao P, Hao X, Xu H, Zhan P, Liu X. Recent progress in the structural modification and pharmacological activities of ligustrazine derivatives. Eur J Med Chem. 2018;147:150-162. doi:10.1016/j. ejmech.2018.01.097

15. Wang X, Chen X. Study on the effects of tetramethylpyrazine on tumor cells: survey and prospects. Zhongguo Zhong Yao Za Zhi= Zhongguo Zhongyao Zazhi= China Journal of Chinese Materia Medica. 2003;28(4):295-298.

16. Wang X-B, Wang -S-S, Zhang Q-F, et al. Inhibition of tetramethylpyrazine on P-gp, MRP2, MRP3 and MRP5 in multidrug resistant human hepatocellular carcinoma cells. Oncol Rep. 2010;23(1): 211-215.

17. Wang P, She G, Yang Y, et al. Synthesis and biological evaluation of new ligustrazine derivatives as anti-tumor agents. Molecules. 2012;17 (5):4972-4985. doi:10.3390/molecules 17054972

18. Ai Y, Zhu B, Ren C, et al. Discovery of new monocarbonyl ligustrazine-curcumin hybrids for intervention of drug-sensitive and drugresistant lung cancer. $J$ Med Chem. 2016;59(5):1747-1760. doi:10.1021/acs.jmedchem.5b01203

19. Xu B, Chu F, Zhang Y, et al. A series of new ligustrazine-triterpenes derivatives as anti-tumor agents: design, synthesis, and biological evaluation. Int J Mol Sci. 2015;16(9):21035-21055. doi:10.3390/ ijms 160921035

20. Xu B, Yan W-Q, Xu X, et al. Combination of amino acid/dipeptide with ligustrazine-betulinic acid as antitumor agents. Eur J Med Chem. 2017;130:26-38. doi:10.1016/j.ejmech.2017.02.036

21. Chu F, Xu X, Li G, et al. Amino acid derivatives of ligustrazine-oleanolic acid as new cytotoxic agents. Molecules. 2014;19(11):18215-18231. doi:10.3390/molecules 191118215
22. Gottlieb HE, Kotlyar V, Nudelman A. NMR chemical shifts of common laboratory solvents as trace impurities. J Org Chem. 1997;62(21):7512-7515. doi:10.1021/jo971176v

23. Strahl BD, Allis CD. The language of covalent histone modifications. Nature. 2000;403(6765):41. doi:10.1038/47412

24. Mosmann T. Rapid colorimetric assay for cellular growth and survival: application to proliferation and cytotoxicity assays. J Immunol Methods. 1983;65(1-2):55-63. doi:10.1016/0022-1759(83)90303-4

25. Eldehna WM, Abo-Ashour MF, Ibrahim HS, et al. Novel [(3-indolylmethylene) hydrazono] indolin-2-ones as apoptotic anti-proliferative agents: design, synthesis and in vitro biological evaluation. J Enzyme Inhib Med Chem. 2018;33(1):686-700. doi:10.1080/14756366.2017.1421181

26. Almahli H, Hadchity E, Jaballah MY, et al. Development of novel synthesized phthalazinone-based PARP-1 inhibitors with apoptosis inducing mechanism in lung cancer. Bioorg Chem. 2018;77:443-456. doi:10.1016/j.bioorg.2018.01.034

27. Vilar S, Cozza G, Moro S. Medicinal chemistry and the molecular operating environment (MOE): application of QSAR and molecular docking to drug discovery. Curr Top Med Chem. 2008;8 (18):1555-1572. doi:10.2174/156802608786786624

28. Fournier J-F, Bhurruth-Alcor Y, Musicki B, et al. Squaramides as novel class I and IIB histone deacetylase inhibitors for topical treatment of cutaneous t-cell lymphoma. Bioorg Med Chem Lett. 2018;28 (17):2985-2992. doi:10.1016/j.bmcl.2018.06.029

29. Keshelava N, Davicioni E, Wan Z, et al. Histone deacetylase 1 gene expression and sensitization of multidrug-resistant neuroblastoma cell lines to cytotoxic agents by depsipeptide. J Natl Cancer Inst. 2007;99 (14):1107-1119. doi:10.1093/jnci/djm044

30. Eckschlager T, Plch J, Stiborova M, Hrabeta J. Histone deacetylase inhibitors as anticancer drugs. Int J Mol Sci. 2017;18(7):1414. doi:10.3390/ijms 18071414

31. Wang Z, Sun H, Yao X, et al. Comprehensive evaluation of ten docking programs on a diverse set of protein-ligand complexes: the prediction accuracy of sampling power and scoring power. Phys Chem Chem Phys. 2016;18(18):12964-12975. doi:10.1039/C6CP01555G

\section{Publish your work in this journal}

Drug Design, Development and Therapy is an international, peerreviewed open-access journal that spans the spectrum of drug design and development through to clinical applications. Clinical outcomes, patient safety, and programs for the development and effective, safe, and sustained use of medicines are a feature of the journal, which has also been accepted for indexing on PubMed Central. The manuscript management system is completely online and includes a very quick and fair peer-review system, which is all easy to use. Visit http://www. dovepress.com/testimonials.php to read real quotes from published authors. 